\title{
Essential data elements for electronic cardiovascular medical record systems in Iran
}

\author{
Abbas Sheikhtaheri $^{*(\mathbb{D})}$, Farid Khorami ${ }^{2}$ (D) Hedyeh Mohammadzadeh $^{3}$ \\ ${ }^{1}$ Associate Professor, Department of Health Information Management, School of Health Management and Information Sciences, Iran \\ University of Medical Sciences, Tehran, Iran \\ ${ }^{2}$ Department of Health Information Technology, Faculty of Para-Medicine, Hormozgan University of Medical Sciences, Bandar Abbas, Iran \\ ${ }^{3}$ Department of Health Information Management, School of Health Management and Information Sciences, Iran University of Medical \\ Sciences, Tehran, Iran
}

\begin{tabular}{l}
\hline Article Info \\
\hline $\begin{array}{l}\text { Article type: } \\
\text { Research }\end{array}$ \\
\hline Article History: \\
Received: 2020-10-17 \\
Accepted: 2020-12-05 \\
Published: 2021-01-04 \\
* Corresponding author: \\
Abbas Sheikhtaheri \\
Associate Professor, Department of \\
Health Information Management, \\
School of Health Management and \\
Information Sciences, Iran University \\
of Medical Sciences, Tehran, Iran
\end{tabular}

Email: sheikhtaheri.a@iums.ac.ir

Keywords:

Minimum Data Set

Data Element

Electronic Medical Record

Electronic Health Record

Cardiovascular Disease
A B S T R A C T

Introduction: Electronic medical records play an important role in the management of patients. In order to develop cardiovascular electronic medical record systems, determining minimum data set is necessary. This study aimed to determine the essential data elements for electronic cardiovascular medical record systems.

Material and Methods: Medical records of patients with cardiovascular diseases and also the literature were reviewed to develop a questionnaire regarding the data elements. 87 cardiovascular specialists and residents as well as 50 nurses working in cardiovascular departments of hospitals affiliated with Iran University of Medical Sciences participated in the study. The data elements with at least $75 \%$ of agreement were considered essential for electronic medical records. Data were analyzed using descriptive statistics in SPSS software.

Results: The essential data elements were classified in 29 classes including admission, death, patients' main complaints, clinical signs, observations, medications, cardiac surgery, risk factors, laboratory and pathology results, consultation, resuscitation, anesthetic, electrocardiography, blood transfusion or blood products, rehabilitation measures, angiography/venography, exercise testing, endoscopy/colonoscopy, medical imaging, echocardiography, nursing interventions, allergies and side effects, therapeutic implantations, cardiac examinations, physical examinations, angina, referrals, social backgrounds and history. Totally, out of 276 data elements, 245 elements were identified as the essential data elements for electronic cardiovascular medical record systems.

Conclusion: In this study, essential data elements were defined for electronic cardiovascular medical records. Identifying cardiovascular minimum data set will be an effective step towards integrating and improving the management of these patients' information.

\section{Cite this paper as:}

Sheikhtaheri A, Khorami F, Mohammadzadeh H. Essential Data Elements for Electronic Cardiovascular Medical Record Systems in Iran. Front Health Inform. 2021; 10: 54. DOI: 10.30699/fhi.v10i1.252

\section{INTRODUCTION}

Cardiovascular diseases (CVDs) are among important causes of disability and death in the world [1]. According to the World Health Organization (WHO), CVDs are the number 1 cause of death in the world and 17.9 million people annually die from CVDs. This accounts $31 \%$ of all deaths globally [2]. The 2020 report from American Hospital Association indicates that almost 17.8 million deaths are attributed to CVDs globally, which indicates a 21.1\% increase from 2007.
The age-adjusted death rate per 100000 is 233.1 which represents a 10.3\% decrease from 2007 . Overall, the crude prevalence of CVDs is 485.6 million cases in 2017, a $28.5 \%$ increase and the age-adjusted prevalence rate is 6081.6 per 100000 , and $0.2 \%$ increase from 2007 [ $\underline{3}$ ]. Based on the WHO, over $75 \%$ of CVDs-related deaths are occurred in low and middle income countries [2]. A study in 2017 in Iran showed that cardiovascular disease accounted for 33-38 percent of deaths (approximately 26-30 million) and 23 percent of disabilities (approximately 
18 million) [4]].

Accurate and exchangeable health information is an essential prerequisite for providing optimal health care and the fragmented information also has undesirable effects on current and future health care for patients and consequently imposes high costs on health care systems [5]. However, most medical records of patients with cardiovascular diseases are also paper-based, and existing information systems support a limited specialized data set in this field [6]. Furthermore, poor and non-standard documentation of health information in medical records of these patients leads to poor management of the disease, which has negative consequences for patients [1].

Paper records do not meet the needed standards for health information systems. Therefore, application of computerized health information systems, especially, electronic medical records (EMR) has expanded [7]. Minimum Data Set (MDS) is required to collect quality data and is a prerequisite for developing electronic medical record systems (EMR) [ $\underline{8}-\underline{10}]$. Therefore, the development of data sets in a uniform and standardized format at the national level could be the most important step to develop EMR systems [ $\underline{11}$, 12].

Some studies have been conducted worldwide to introduce standardized data sets for cardiovascular diseases for different purposes [13-16]; however, only two studies have specifically focused on developing data sets for cardiovascular EMRs/EHRs $[13,14]$. Jeffery et al data elements for outpatient EMRs for pediatrics which contained 102 general concepts and eight categories [13]. Weintraub et al. also provided a list of data elements for electronic health records for cardiovascular diseases [14]. In Iran, many studies have been conducted to develop and standardize data sets for documentation of patients' health data in electronic systems $[\underline{12}, \underline{17}$, 18]; however, to our knowledge, there is no study regarding to the development of data sets for a cardiovascular EMR system.

Considering the importance of cardiovascular diseases and given that to developing an EMR for cardiovascular diseases requires the development of data elements, this study aimed to determine the essential data elements for cardiovascular EMR in Iran so that system developers can develop a cardiovascular EMR system based on agreed-upon data elements.

\section{MATERIAL AND METHODS}

This descriptive cross-sectional study conducted in two phases. In the first phase, 50 paper-based medical records of patients with cardiovascular disease from Hazrat Rasoul hospital were randomly selected based on the ICD-10 blocks of cardiovascular diseases (five records from each block). The content of medical records was reviewed and the data items had been documented in each record were extracted using a data extraction form. In addition, all standardized clinical and administrative forms in this hospital were reviewed. We classified the identified data elements in several categories. Furthermore, the related literature was reviewed to identify related data elements $[\underline{13}-16,19]$.

In the second phase, a questionnaire contained different cardiovascular data elements identified from previous phase was developed. The questionnaire included a list of data elements in 29 classes (admission, death, patients' main complaints, clinical signs, observations, medicine, cardiac surgery, risk factors, laboratory and pathology, consultation, resuscitation, anesthetic, electrocardiography, blood transfusion or blood products, rehabilitation measures, angiography/venography, exercise testing, endoscopy/colonoscopy, medical imaging, echocardiography, nursing interventions, allergies and side effects, implantable remedies, cardiac examinations, physical examinations, angina, referrals, social backgrounds and history). The answer of each question had two options: necessary or not necessary. Content of the questionnaire was validated by three cardiovascular specialists, health information management and medical informatics experts. To evaluate the reliability of questionnaire, Richardson's coefficient method was used (0.975) which indicates a very high reliability of the instrument.

The sample consisted of all 87 cardiovascular specialists and residents and 50 nurses of cardiovascular wards of all hospitals affiliated with Iran University of Medical Sciences. The questionnaire was distributed to the physicians and nurses and they were asked to identify the necessity of each data elements. From 137 distributed questionnaires, 99 questionnaires were completed and collected (Response rate was $72.2 \%$ ).

Data were analyzed using descriptive statistics in SPSS software (version 22) and frequency and percentage were calculated for each data element. Data elements with a high agreement (at least $75 \%$ of participants considered it as necessary) were selected as the main data elements for cardiovascular EMRs.

\section{RESULTS}

According to Table 1, the total number of participants was $99,56.5 \%$ of whom were female. The highest age group was 30-40 years old (60.6\%). Most of the participants had 5-10 years of experiences. Among them, $52.5 \%$ were physicians.

Table 2 shows the frequency of data elements for cardiovascular electronics medical records. Most of 
the data elements were related to the history class (18\%), risk factors (11\%) and clinical symptoms (10\%). Table 3 also presents the approved data elements as well as the deleted data elements for each class.

\section{Table 1: Characteristics of the participants}

\begin{tabular}{|c|l|c|c|}
\hline \multicolumn{2}{|c|}{$\begin{array}{c}\text { Demographic } \\
\text { characteristics }\end{array}$} & Frequency & Percentage \\
\hline \multirow{3}{*}{ Gender } & Male & 43 & 43.4 \\
\cline { 2 - 4 } & Female & 56 & 56.6 \\
\hline
\end{tabular}

\begin{tabular}{|l|l|c|c|}
\hline \multirow{4}{*}{ Age } & $<30$ & 15 & 15.1 \\
\cline { 2 - 4 } & $30-40$ & 60 & 60.6 \\
\cline { 2 - 4 } & $>40$ & 24 & 24.3 \\
\hline \multirow{3}{*}{$\begin{array}{l}\text { Years of } \\
\text { experience }\end{array}$} & $<5$ & 35 & 35.3 \\
\cline { 2 - 4 } & $5-10$ & 38 & 38.3 \\
\cline { 2 - 4 } $\begin{array}{l}\text { Field of } \\
\text { study }\end{array}$ & $>10$ & 27 & 27.4 \\
\hline \multirow{4}{*}{$\begin{array}{l}\text { Education } \\
\text { level }\end{array}$} & Medical & 52 & 52.5 \\
\cline { 2 - 4 } & Nursing & 47 & 47.5 \\
\cline { 2 - 4 } & Machelor & 40 & 40.4 \\
\cline { 2 - 4 } & Master & 7 & 7.07 \\
\cline { 2 - 4 } & Specident & 33 & 33.3 \\
\cline { 2 - 4 } & Fellowship & 10 & 9.09 \\
\hline
\end{tabular}

Table 2: Frequency of identified data elements

\begin{tabular}{|c|c|c|c|}
\hline Class & $\begin{array}{l}\text { Total number of } \\
\text { data elements }\end{array}$ & $\begin{array}{l}\text { Number of data } \\
\text { elements removed }\end{array}$ & $\begin{array}{l}\text { Number of data } \\
\text { elements remained }\end{array}$ \\
\hline Admission & 11 & 2 & 9 \\
\hline Death & 6 & 0 & 6 \\
\hline Patients' main complaints & 7 & 1 & 6 \\
\hline Clinical signs & 25 & 2 & 23 \\
\hline Observations & 6 & 0 & 6 \\
\hline Medicine & 10 & 2 & 8 \\
\hline Cardiac surgery & 10 & 2 & 8 \\
\hline Risk factors & 26 & 3 & 23 \\
\hline Laboratory and pathology & 7 & 2 & 5 \\
\hline Resuscitation & 3 & 0 & 3 \\
\hline Electrocardiography & 5 & 0 & 5 \\
\hline Anesthetic & 10 & 1 & 9 \\
\hline $\begin{array}{l}\text { Blood transfusion or blood } \\
\text { Products }\end{array}$ & 7 & 0 & 7 \\
\hline Rehabilitation measures & 8 & 2 & 6 \\
\hline Angiography / venography & 4 & 0 & 4 \\
\hline Exercise testing & 7 & 0 & 7 \\
\hline Endoscopy / colonoscopy & 2 & 0 & 2 \\
\hline Medical imaging & 7 & 1 & 6 \\
\hline Echocardiography & 3 & 0 & 3 \\
\hline Nursing interventions & 4 & 0 & 4 \\
\hline Allergies and side effects & 4 & 0 & 4 \\
\hline Therapeutic implants & 7 & 5 & 2 \\
\hline Cardiac examinations & 13 & 0 & 13 \\
\hline Physical examinations & 11 & 2 & 9 \\
\hline Angina & 2 & 0 & 2 \\
\hline Referrals & 10 & 5 & 5 \\
\hline Social backgrounds & 13 & 0 & 13 \\
\hline $\begin{array}{l}\text { History ( Disease history, Surgical } \\
\text { history, Family history) }\end{array}$ & 43 & 0 & 43 \\
\hline
\end{tabular}

Table 3: Data elements for electronic cardiovascular medical record systems

\begin{tabular}{|l|l|l|}
\hline Main data classes & Approved data elements & $\begin{array}{l}\text { Deleted data } \\
\text { elements }\end{array}$ \\
\hline Admission & $\begin{array}{l}\text { Kind of admission (including outpatient, inpatient, emergency), Admission } \\
\text { date and time, Referral from (center name), physician full name, Encounter } \\
\text { date, Encounter priority, Reason of admission, Hospitalization place, } \\
\text { Diagnosis code }\end{array}$ & $\begin{array}{l}\text { Referral } \\
\text { physician name, } \\
\text { Referral } \\
\text { physician } \\
\text { specialty }\end{array}$ \\
\hline Death & $\begin{array}{l}\text { Main cause of death, Underlying cause of death, External cause of death, } \\
\text { Date of death, Patient age at death, Place of death }\end{array}$ & - \\
\hline Patients' main & Chief complaint, Onset of chief complaint, Chief complaint period, & Severity of the \\
\hline
\end{tabular}




\begin{tabular}{|c|c|c|}
\hline Main data classes & Approved data elements & $\begin{array}{l}\text { Deleted data } \\
\text { elements }\end{array}$ \\
\hline complaint & $\begin{array}{l}\text { Frequency of chief complaint, Duration of chief complaint, Disease name, } \\
\text { Body temperature, Heart rate, Breathing rate, Oxygen saturation, Chest } \\
\text { pain, Location of chest pain, Chest pain quality, Quality of heart palpitations, } \\
\text { Tachycardia, Systolic and diastolic blood pressure, Cyanosis, Heart beat }\end{array}$ & main complaint \\
\hline Clinical signs & $\begin{array}{l}\text { Orthopnea, Dyspnea, Deep Vein Thrombosis, Hematoma, Sinus heart } \\
\text { rhythm, AF heart rhythm, Ischemic cardiomyopathy, Asystole rhythm, } \\
\text { Murmur, Confusion }\end{array}$ & $\begin{array}{l}\text { Height, Stenosis } \\
\text { of mitral valve }\end{array}$ \\
\hline Observations & $\begin{array}{l}\text { Weight, Body mass index (BMI), Activity related data (patient activity type), } \\
\text { Diet data (type of diet), Pregnancy status (Pregnancy status, Gestational } \\
\text { age) }\end{array}$ & - \\
\hline Medicine & $\begin{array}{l}\text { Medication name (Aspirin, Cyclooxygenase Inhibitor, Beta Blocker, Calcium } \\
\text { Channel Blocker), Medication dosage, Time to start taking medication, Date } \\
\text { of prescription, Start date of medication, Route of administration, Time to } \\
\text { stop medication, Side effects }\end{array}$ & $\begin{array}{l}\text { Drug form } \\
\text { (solid-liquid), } \\
\text { Frequency of } \\
\text { drug use }\end{array}$ \\
\hline Cardiac surgery & $\begin{array}{l}\text { Type of operation (valve replacement, pacemaker, etc), Method of } \\
\text { operation, Descriptions of actions and findings, Post-Operative diagnosis, } \\
\text { Intraoperative complications, Postoperative complications, Operation date }\end{array}$ & $\begin{array}{l}\text { Surgery code, } \\
\text { Surgery time }\end{array}$ \\
\hline Risk factors & $\begin{array}{l}\text { History of coronary heart disease (CHD), Age at diagnosis for CHD, } \\
\text { Symptoms of CHD, Myopathy, Other muscular dystrophies that cause } \\
\text { myopathy, Kawasaki disease, Onset time of Kawasaki disease, Patient age at } \\
\text { onset of first Kawasaki symptoms, Kawasaki symptoms, interventions for } \\
\text { Kawasaki disease, Medications for Kawasaki disease, Patients' reactions to } \\
\text { interventions conducted for Kawasaki disease, Complications of Kawasaki } \\
\text { interventions, Rheumatic fever, Onset time of rheumatic fever, Patient's age } \\
\text { at the onset of the first symptoms of rheumatic fever, Symptoms of } \\
\text { rheumatic fever, Surgery conducted for rheumatic fever, Other risk factors, } \\
\text { Family history of heart disease }\end{array}$ & $\begin{array}{l}\text { Kawasaki } \\
\text { classification by } \\
\text { Aneurysm, } \\
\text { Laboratory } \\
\text { findings of } \\
\text { Kawasaki, Time } \\
\text { of interventions }\end{array}$ \\
\hline $\begin{array}{l}\text { Laboratory and } \\
\text { pathology }\end{array}$ & $\begin{array}{l}\text { Test name (Creatinine, Total blood cholesterol, Low density lipoprotein, } \\
\text { High density lipoprotein, Ian C-Hemoglobin, Sodium, Hematocrit, Nitrogen } \\
\text { Urea, etc.), Test results, Patient status, Pathology date, Pathology report }\end{array}$ & $\begin{array}{l}\text { Test result date, } \\
\text { Test date }\end{array}$ \\
\hline Consultation & Type of consultation, Diagnosis, Consultant physician's advice & $\begin{array}{l}\text { Consultation } \\
\text { date, } \\
\text { Consultation } \\
\text { time }\end{array}$ \\
\hline Resuscitation & Resuscitation date, Resuscitation time, Resuscitation result & - \\
\hline Electrocardiography & $\begin{array}{l}\text { ECG date, ECG interpretation, Diagnosis, Location of the ECG change, Type of } \\
\text { ECG changes }\end{array}$ & - \\
\hline Anesthesia & $\begin{array}{l}\text { Anesthesia date, Anesthesia type, Anesthesia time, Anesthesia-related care, } \\
\text { Patient status at onset of anesthesia, Vital signs during anesthesia, Vital } \\
\text { signs at the end of anesthesia, Drugs, Complications }\end{array}$ & $\begin{array}{l}\text { Anesthesia } \\
\text { technique }\end{array}$ \\
\hline $\begin{array}{l}\text { Blood transfusion or } \\
\text { blood products }\end{array}$ & $\begin{array}{l}\text { Blood type, Required blood unit, Number of blood products requested, } \\
\text { Reason for requesting blood, Taking medications at the time of blood } \\
\text { transfusion, Blood transfusion intervals, Blood filter status }\end{array}$ & - \\
\hline $\begin{array}{l}\text { Rehabilitation } \\
\text { measures }\end{array}$ & $\begin{array}{l}\text { Rehabilitation service name, Reactions to treatment, Expected outcome of } \\
\text { treatment, Rehabilitation date, Daily evaluation, Methods of rehabilitation }\end{array}$ & $\begin{array}{l}\text { Start time } \\
\text { End time }\end{array}$ \\
\hline $\begin{array}{l}\text { Angiography / } \\
\text { venography }\end{array}$ & $\begin{array}{l}\text { Angiography/Venography date, Angiography/Venography result, Targeted } \\
\text { vessel, Stenosis severity pre/post procedure }\end{array}$ & - \\
\hline Exercise test & $\begin{array}{l}\text { Exercise test date, Exercise test time , Exercise stress test interpretation, } \\
\text { Diagnosis, Phase, Grade, Speed }\end{array}$ & - \\
\hline $\begin{array}{l}\text { Endoscopic / } \\
\text { colonoscopy }\end{array}$ & Endoscopy / colonoscopy date, Endoscopy / colonoscopy results & - \\
\hline Medical imaging & $\begin{array}{l}\text { Imaging service name, Organ name, Laterality, Report and interpretation of } \\
\text { radiologists, Radiologist diagnosis, Imaging date and time }\end{array}$ & Technique used \\
\hline Echocardiography & Echocardiography date, Findings and results & - \\
\hline $\begin{array}{l}\text { Nursing } \\
\text { interventions }\end{array}$ & $\begin{array}{l}\text { Nurse observations, Type of actions, Date and time of actions, Nurse } \\
\text { reports }\end{array}$ & - \\
\hline $\begin{array}{l}\text { Allergies and side } \\
\text { effects }\end{array}$ & Allergy, Allergen name, Specific food habit, Description of food habit & - \\
\hline $\begin{array}{l}\text { Implantable } \\
\text { remedies }\end{array}$ & Device name, Number & $\begin{array}{l}\text { Manufacturer, } \\
\text { Model, Size, } \\
\text { Serial Number, } \\
\text { Other features }\end{array}$ \\
\hline Cardiac examination & Chest tightening, Pericardial touch, PMI type, Heart sounds, S1 heart sound, & - \\
\hline
\end{tabular}




\begin{tabular}{|c|c|c|}
\hline Main data classes & Approved data elements & $\begin{array}{l}\text { Deleted data } \\
\text { elements }\end{array}$ \\
\hline & $\begin{array}{l}\text { S2 heart sound, Location of heart sounds, Heart sounds (murmur phase), } \\
\text { Heart sounds (heart murmurs), Heart sounds( time), Heart sounds (heart } \\
\text { murmurs), Heart murmurs (features) }\end{array}$ & \\
\hline $\begin{array}{l}\text { Physical } \\
\text { examination }\end{array}$ & $\begin{array}{l}\text { General appearance, Skin examinations, Abdominal examinations, Hearing } \\
\text { aids, Abdominal examinations (touch), Abdominal inspection, } \\
\text { Examinations of organs, Examination of organs when capillaries are filled, } \\
\text { Examinations of organs (pulse amplitude), Examination of the organs } \\
\text { (location of the pulse), Examination of organs (delay of radial and femoral } \\
\text { artery) }\end{array}$ & $\begin{array}{l}\text { Genital } \\
\text { examinations, } \\
\text { External } \\
\text { genitalia }\end{array}$ \\
\hline Angina & Date and time of the first angina, Date and time of the last angina & - \\
\hline Referrals & $\begin{array}{l}\text { Cause of referrals, Date of referrals, Hospital of origin, Destination hospital, } \\
\text { Patient triage level }\end{array}$ & $\begin{array}{l}\text { Transmission } \\
\text { time, Origin } \\
\text { ward, } \\
\text { Destination } \\
\text { ward, Referral } \\
\text { mode, Referral } \\
\text { level }\end{array}$ \\
\hline Social context & $\begin{array}{l}\text { Alcohol/ Drug/ Cigarette/Hookah consumption, } \\
\text { Type of drug, Name of drug used, Dosage of drugs, Caffeine intake, Calorie } \\
\text { intake, Liquid consumption, Salt consumption, Experience with chemicals, } \\
\text { History of tobacco use, Experience of working in mines, Having pets }\end{array}$ & $\begin{array}{l}\text { Need to a } \\
\text { translator }\end{array}$ \\
\hline $\begin{array}{l}\text { History (surgery } \\
\text { history) }\end{array}$ & $\begin{array}{l}\text { Surgery name (coronary artery bypass, angioplasty, Non-cardiac surgery, } \\
\text { dialysis), Date of surgery }\end{array}$ & - \\
\hline $\begin{array}{l}\text { History (family } \\
\text { history) }\end{array}$ & $\begin{array}{l}\text { Coronary artery disease, Sudden cardiac death , Myocardial infarction, } \\
\text { Stroke, Arrhythmia, Syncope, Hypertension , Increased blood lipids, } \\
\text { Cardiovascular disease and cardiovascular risk factors }\end{array}$ & \\
\hline Main data classes & Approved data elements & $\begin{array}{l}\text { Deleted data } \\
\text { elements }\end{array}$ \\
\hline $\begin{array}{l}\text { History (history of } \\
\text { disease) }\end{array}$ & $\begin{array}{l}\text { Renal artery disease, Chest pain or angina, Heart failure, Syncope, } \\
\text { Hypertension, Dyslipidemia, Diabetes, Aneurysm, Transient ischemia attack, } \\
\text { Chronic pulmonary disease, Chronic kidney disease, History of use of } \\
\text { unauthorized drugs and narcotic, AIDS, Atrial rhythm disorder, } \\
\text { Supraventricular tachycardia, Irregularity in ventricular heart rate, Venous } \\
\text { blood clot, Depression, Coronary artery disease Cerebral artery disease, } \\
\text { Peripheral artery disease, Aortic disease, Myocardial infarction, Sudden } \\
\text { cardiac arrest, Heart failure, Abnormal heart examinations, Pulmonary } \\
\text { hypertension, Lack of weight gain, Pregnancy, Types of syndromes, History } \\
\text { of drug use, Allergic reactions }\end{array}$ & - \\
\hline
\end{tabular}

\section{DISCUSSION}

Information management is one of the most important issues in the diagnosis and treatment of cardiovascular diseases. Developing data elements for cardiovascular diseases facilitate the continuous, accurate and complete documentation of patients' information using standardized terms used to describe cardiovascular diseases and interventions [15]. However no research has been conducted to determine the data elements for Iranian EMRs for cardiovascular diseases. In the first step, it is founded that cardiovascular diseases were not documented very well paper- based medical records. According to our results, among 276 suggested data elements for cardiovascular EMRs, 244 data elements were approved and classified into 29 different classes including admission, death, main complaints, clinical signs, observations, medications, cardiac surgery, risk factors, laboratory and pathology, consultation, resuscitation, anesthesia, electrocardiography, blood transfusion or blood products, rehabilitation measures, angiography/venography, exercise test, endoscopy/colonoscopy, medical imaging, echocardiography, nursing interventions, allergies and side effects, implants, cardiac examinations, physical examination, angina, transmissions, social backgrounds, and history.

Jeffrey et al. [13] considered an outpatient EMR for congenital and pediatric cardiovascular diseases and suggested different data elements including physical examinations, clinical signs, and cardiac examinations as key data elements. These findings are consistent with our results regarding the required data elements for an EMR for patients with cardiovascular diseases. Additionally, Asselbergs et al. [16] conducted a study to identify standardized clinical data elements in cardiovascular patients for optimal care, quality control, and research. In this study, demographic data elements (date of birth, age, gender, membership date), general aspects (physicians' treatment for referrals), medical history 
(acute myocardial infarction, myocardial infarction, aneurysm, coronary artery bypass surgery, ischemia attack), chronic kidney disease, hypertension, high blood lipids, history of delivery, family history of cardiovascular disease, lifestyle (physical activity, alcohol consumption, smoking), physiological measurements (height, weight, blood pressure, heart rate), laboratory measurements (blood lipids, triglycerides, cratine, hemoglobin), heart failure, cerebral ischemia, arterial aneurysm, diabetes and hypertension are considered essential. These data elements are also considered necessary in our study and were included in the medical history data elements, social context, clinical symptoms, and laboratory data classes. Weintraub et al. [14] also introduced a list of data elements including history and physical examinations, family history, patient evaluation data, laboratory data, cardiac therapies, cardiac implants, and medicines which are consistent with our study.

Some limitations of this study should be considered. Reviewing the medical records in the first step was done only at the Hazrat Rasoul Hospital. Additionally the participants were also from hospitals affiliated with Iran University of Medical Sciences. Therefore, the results may not be generalizable to the whole country.

In this study, we considered the data elements for general EMR for cardiovascular diseases and we did not focus on a specific type of disease. CVDs includes a variety of diseases such as coronary heart disease, congenital heart diseases, etc. which may require more specialized data elements. Therefore, more studies in this regard are highly recommended.

\section{CONCLUSION}

There is no standard in Iran for necessary data elements for EMRs for cardiovascular diseases. Therefore, introduction and standardization of data elements required for EMRs for patients with cardiovascular diseases are necessary. This study introduced 244 data elements in 29 different classes for electronic cardiovascular medical records.

\section{AKNOWLEDGMENTS}

This article is part of a thesis entitled 'Designing a Conceptual Model for Electronic Cardiovascular Medical Record" which is supported by Iran University of Medical Sciences.

This study received ethical approval from Ethics Committee of Iran University of Medical Sciences (IR.IUMS.REC 1396.9411304006).

\section{AUTHOR'S CONTRIBUTION}

The authors agree on this final form of the manuscript, and attested that all authors contributed in the final draft of the manuscript.

\section{CONFLICTS OF INTEREST}

The authors declare no conflicts of interest regarding the publication of this study.

\section{FINANCIAL DISCLOSURE}

No financial interests related to the material of this manuscript have been declared.

\section{REFERENCES}

1. Salem M, Alali A, Bashwar Z. Improving documentation of cardio-vascular disease risk in medical records of diabetic patients attending non communicable disease clinics at West Bay health center in Qatar. BMJ Qual Improv Rep. 2015; 4(1): u207778.w3190. PMID: 26734364 DOI: 10.1136/bmjquality.u207778.w3190 [ubMed]

2. World Health Organization. Cardiovascular diseases (CVDs) [Internet]. 2017 [cited: 25 Nov 2020]. Available from: https://www.who.int/en/newsroom/fact-sheets/detail/cardiovascular-diseases(cvds)

3. Virani Salim S, Alonso A, Benjamin EJ, Bittencourt MS, Callaway CW, Carson AP, et al. Heart disease and stroke statistics-2020 update: A report from the American Heart Association. Circulation. 2020; 141(9): e139-e596. PMID: 31992061 DOI: 10.1161/CIR.0000000000000757 [PubMed]

4. Gamissi J, Hosseinian A. Spatial statistics application in comparative study of Ardabil province counties status in the basis of hospitalization rate due to coronary disease. Journal of Health and Care. 2017; 19(3): 168-81.

5. Safdari R. Electronic health record system. Tehran: Jafari Publication; 2011.

6. Carpeggiani C, Dalmiani S, Taddei A, Franchi D, Michelassi C, Chelozzi L, et al. Use of an electronic medical record in a department of cardiology. Computers in Cardiology. Cambridge: IEEE; 2000.

7. Ghazi Saeidi M, Moghimi Araghi S, Babadi S. Determining the required minimum data set and data elements to create a web-based electronic record for glaucoma patients. Journal of Payavard Salamat. 2018; 11(6): 675-84.

8. Gholami Parizad E, Sharifian R. Designing the minimum data set for Iranian children' health records. Journal of Ilam University of Medical Sciences. 2016; 24(1): 114-25.

9. Zahmatkeshan M, Farjam M, Mohammadzadeh N, Noori T, Karbasi Z, Safdari R, et al. Design of infertility monitoring system: Minimum data set approach. J Med Life. 2019; 12(1): 56-64. PMID: 31123526 DOI: 10.25122/jml-2018-0071 [PubMed] 
10. Karen L. Use of the SGNA minimum data set in the clinical area. Gastroenterol Nurs. 2005; 28(1): 59-60. PMID: $\quad 15738737$ DOI: $10.1097 / 00001610-$ 200501000-00015 [PubMed]

11. Mohammadi A, Ahmadi M, Bashiri A, Nazemi Z. Designing the minimum data set for orthopedic injuries. Journal of Clinical Research in Paramedical Sciences. 2014; 3(2): 75-83.

12. Hashemi N, Sheikhtaheri A, Hashemi NS, Rawassizadeh R. Electronic medical records for mental disorders: What data elements should these systems contain? Stud Health Technol Inform. 2019; 260: 25-32. PMID: 31118315 [PubMed]

13. Boris JR, Béland MJ, Bergensen LJ, Colan SD, Dangel J, Daniels CJ, et al. 2017 AHA/ACC key data elements and definitions for ambulatory electronic health records in pediatric and congenital cardiology: A report of the american college of cardiology/american heart association task force on clinical data standards. J Am Coll Cardiol. 2017; 70(8): 1029-95. PMID: 28716477 DOI: 10.1016/j.jacc.2017.06.027 [PubMed]

14. Weintraub WS, sKarlsberg RP, Tcheng JE, Boris JR, Buxton AE, Dove JT, et al. ACCF/AHA 2011 key data elements and definitions of a base cardiovascular vocabulary for electronic health records: a report of the American College of Cardiology Foundation/American Heart Association task force on clinical data standards. J Am Coll Cardiol. 2011; 58(2): 202-22. PMID: 21652161 DOI: 10.1016/j.jacc.2011.05.001 [PubMed]
15. Douglas PS, Carabello BA, Lang RM, Lopez L, Pellikka PA, Picard MH, et al. 2019 ACC/AHA/ASE Key data elements and definitions for transthoracic echocardiography: a report of the American College of Cardiology/American Heart Association task force on clinical data standards and the American Society of Echocardiography. Circ Cardiovasc Imaging. 2019; 12(7): e000027. PMID: 31233331 DOI: 10.1161/HCI.0000000000000027 [PubMed]

16. Asselbergs FW, Visseren FL, Bots ML, de Borst GJ, Buijsrogge MP, Dieleman JM, et al. Uniform data collection in routine clinical practice in cardiovascular patients for optimal care, quality control and research: The Utrecht cardiovascular cohort. Eur J Prev Cardiol. 2017; 24(8): 840-47. PMID: 28128643 DOI: $10.1177 / 2047487317690284$ [PubMed]

17. Langarizadeh $\mathrm{M}$, Gholinezhad M. A minimum data set of laboratory reporting system for exchanging with electronic health record system in Iran. Journal of Health Administration. 2017; 19(66): 61-70.

18. Fallahnejad E, Niknam F, Nikandish Nobar R, Zand F, Sharifian R. Development of minimum data set for electronic documentation of progress note in the general intensive care unit. Frontiers in Health Informatics. 2020; 9: 37.

19. HL7. Domain analysis model: Cardiology [Internet]. 2013 [cited: 25 Nov 2020]. Available from: https://www.hl7.org/Special/committees/cardiolog y/index.cfm 